\title{
National Examination Misconduct: Magnitude and Perceived Determinants in Secondary and Preparatory Schools of Bale and West Arsi Zones
}

\author{
Gamachu Gishe Badasa $^{1} \quad$ Ramato Aman Nuri ${ }^{2}$ Mekonnen Gudeta Gizaw ${ }^{3}$ \\ 1.Department of Psychology, College of Education and Behavioral Studies Walabu University, Bale Robe, \\ Ethiopia \\ 2.Department of Public Health, Goba Referral Hospital, MaddaWalabu University, Bale Goba, Ethiopia, \\ 3.Department of Mathematics, College of Natural Science and Computational, Madda Walabu University \\ Correspondence author: Gamachu Gishe P.O.Box: +251247, Bale Robe Ethiopia
}

\begin{abstract}
The main objective of this research was to assess experiences of teachers on national examination cheating encounter and its perceived predictors. We employed Institution based cross-sectional design which was supplemented by qualitative data to address the research objectives. Data was collected from 488 teachers via pretested questionnaire besides, interview and focus group discussion guides which were held with key informants. Before starting data collection process ethical approval letter was obtained from research ethical approval committee. Likewise, verbal consent was obtained from study participants and their confidentiality was kept as the received data used only for research purpose. To address the first objective pie chart was used while multivariate binary logistic regression was computed for the second objective this was via using SPSS version 21. For qualitative data, thematic analysis was done and finally the two data were merged together. The results reveled that about $346(70.9 \%)$ of the study participants were reported as they came across national examination cheating during 2014 and 2015 academic years. Perception of teachers with regard to absence of conducive examination room $(\mathrm{AOR}=.119,95 \% \mathrm{CI}=(.039, .37))$, presence of social linkage $(\mathrm{AOR}=.27,95 \% \mathrm{CI}(.12, .615))$, poor examination supervision $(\mathrm{P}$-value $=0.05))$, parental pressure $(\mathrm{AOR}=3.49,95 \% \mathrm{CI}(.1 .16,10.54)$ were predispose for national examination cheating. Furthermore, the qualitative result suggested many more determinants in addition to the above findings. Finally, the findings suggested that Provision of optimum finance for examination bodies and availing sufficient logistics like transportation facility is very critical and strong supervision system should be established by zonal and district educational offices.
\end{abstract}

Keywords: Ethiopia, national examination cheating, magnitude, determinants

DOI: $10.7176 / \mathrm{JEP} / 10-31-02$

Publication date: November $30^{\text {th }} 2019$

\section{Introduction}

Examination malpractice has been defined by various researchers. For example, Adow, Alio and Thinguri (2015) illustrate it as the activity of students with the aim of having higher grades than they would have achieved on their own. Furthermore, for Onuka and Amusan (2008) it is any dishonest committed by a student on his/her own or in collaboration with others like fellow students, guardians, parents, teachers, head teachers, examination officials, supervisors, invigilators, printers, security officers and anybody or group of people before, during or after examination in order to obtain undeserved marks or grades In general the past study had identified that in secondary school the rate of exam cheating is as high as $78 \%$ (Lee, 2014). If we take the Kenyan secondary schools experiences, students themselves disclosed that they knew as $66 \%$ of their classmates were engaged in it (Adow et al., 2015). Moreover, during national examination in Kenya again examination malpractices are constantly manifested and reported every year when examination results are released (Nyamoita, \& Otieno, 2016).

Examination dishonesty can obscure the objectives of examination and affects the psyche and integrity of top performing students (Alutu \& Aluede, 2006). Thus, its effect ability of students to defend the certificate obtained through examination malpractice, perpetual condemnation of the students' conscience, possibility of unfulfilled dreams and vision, if the students are rusticated from school or terminated at the working place (Oredein cited in Onuka \& Durowoju, 2013).

The available research finding suggested that examination cheating is resulted due to different reasons. For instance, Lee (2014) has found that getting into one's choice of college or university was found to be a determinant factor of national examination cheating. On the other hand, Felix (2015) noted that poor school environment and infrastructure contribute immensely to high rate of examination malpractice. Similarly, Olatunbosun (2009) identified that poor school facilities are some of the factors responsible for examination malpractices in secondary school in Nigeria.

A part from the above evidences, Felix (2015) came up with psychological factor which is inferiority complex as students was participating on cheating to strive not to inferior to their counterparts. It was also found that there 
is positive relationship between students' commitment and cheating behavior. In this regard Khodaie, Moghadamzadeh, and Salehia (2011) noted that the more people are committed to discipline, the less cheating is probable. These scholars also insisted that students who have a history of possible cheating committed fraud in the future for them are more than others. Likewise, insufficient preparation for the examinations among many students was a major cause of examination irregularity (Adow et al., 2015).

According to Bong (2008), perceived expectations, pressures, and support from parents, teachers, and peers can cause students to feel confident or helpless, focus more strongly on a certain type of goal over others. Students with a strong sense of self-efficacy hold firm convictions about their capabilities to successfully learn and perform given academic tasks at desired levels (Schunk cited in Bong, 2008). It was also identified that getting better grades that improve their chances of getting into one's choice of college or university was found to a cause for national examination cheating (Lee, 2014).

On the other hand, the experience of Pakistan secondary schools elucidated that corruption, poor implementation of examination rules; poor morale and economic problem of supervisory staff are among many more determinants of examination cheating (Suleman, Gul, Ambrin \& Kamran, 2015).

The existing trend in Ethiopia has shown us that, though few attempts was done by ministry of education alongside all regionals education Bureau and other development partners via developing general education quality improvement package of which assessment is one of it. However, frequently it has been observed that the security of our national examination is too much complicated than ever before. Therefore, this study was intended to determine the magnitude of national examination cheating encounter and its perceived predictors which could be contributed to the country's strategic planning of ensuring quality education by designing intervention for genuine national assessment that identify students based on their own achievement so that they trust on themselves than waiting for external hands.

\section{Methods and Materials Study design}

Institution based quantitative cross sectional study design supplemented with qualitative method was conducted with the aim of describing the magnitude of national examination cheating and its perceived predictors.

\section{Sample size determination}

The sample size was determined by using single population proportion formula taking examination cheating of $50 \%$ as there is no previous study conducted in Ethiopia that suggests the level of national examination cheating encounter among secondary and preparatory teachers. Margin of error of four point five percent $(4.5 \%)$ and $95 \%$ confidence interval were taken into consideration. Accordingly:

$$
\mathrm{n}=\frac{(\mathrm{Z} \alpha / 2)^{2} \mathrm{P}(1-\mathrm{P})}{\mathrm{d}^{2}} \quad \frac{(1.96)^{2} 0.5(1-0.5)}{(0.045)^{2}}=475
$$

Adding 10\% non-response rate resulted final sample size of 523 .

Study population

The target population of this study was teachers working in secondary and preparatory of West Arsi and Bale zone who took part in national examination as invigilator, supervisor and center chief. We would like to inform our readers that the same population was targeted for article entitled as Perceived Actors of National Examination Cheating: The Case of Bale and West Arsi Zones' Secondary and Preparatory Schools, Oromia Region, Ethiopia that was published on Journal of Equity in Science and Sustainable Development

\section{Sampling procedures}

From the total districts found in Bale and West Arsi zones, fourteen districts were selected by simple random sampling methods. Accordingly, Goba, Gidhir, Goro, Robe, Dinisho, Agarfa and Gololcha were taken from Bale zone while Wondo, Arsi Negele, Hasasa, Kokosa, Dodola, Kofale and Shashemene town were chosen from West Arsi. Subsequently, from each selected districts one high school and one preparatory school were randomly selected by using simple random sampling techniques. The sample size was proportionally allocated to each schools based on the number of teachers currently working in each schools. Teachers from each school were selected by using simple random sampling technique by using their list as sampling frame. For qualitative data, the respective school principals, districts education office head, old hand teachers who worked as supervisor and centers chief, zonal examination heads were purposively selected. Again Gamachu and Ramato (2018) were followed exactly the same procedures since their first published article is part and parcel of the current manuscript.

\section{Data collection methods and tools}

The quantitative data were collected by using self-administered questionnaire which was adapted from Kyei (2014) and Adeyemi (2010) inclining factors towards examination malpractices (IFTEMQ) and examination malpractices predisposition questionnaire (EMPQ) which were used in technical and secondary schools in Ghana and Nigeria 
respectively. Eight trained data collectors were involved in the pre-testing and actual data collection from clients after obtaining consent from study participants. Semi structured interview was conducted with school directors, district education office head and zonal assessment heads to collect qualitative data. In addition, four focus group discussion guides was held with senior teachers to explore their valuable experiences regarding national examination cheating and tape recording was done besides taking note taking. Here also Gamachu and Ramato (2018) used similar methods of data collection tools to gather data from the same participants.

\section{Data Quality assurance}

Starting from the beginning to the end care was given to this work. For instance, criteria was set to collect secondary data for review. Next, tools were pre-tested and arrangement was made. To check the validity of the tools, it was shown to two senior instructors who are experts on the area and their agreement on each item was taken as a mean of validation. Likewise, data collectors were selected with care therefore; senior teachers were received training on how to collect data. The researchers were developed guidelines for supervisory tasks

\section{Data processing and analysis}

The quantitative data was cross-checked, entered, cleaned and analyzed using SPSS version 21 statistical package. The magnitude of national examination cheating was analyzed and presented by graph. However, multivariate binary logistic regression analysis was done to identify factors associated with national examination cheating encounted among teachers. Statistical significance and strength of association between national examination cheating and various independent variables were measured on the basis of adjusted odds ratio and the cross ponding P-value. Statistical significance was declared at P-value of less than 0.05. On the other hand, qualitative data was analyzed thematically.

\section{Ethical consideration}

Research ethical approval letter was taken from Madda Walabu University research, community engagement and technology transfer vice president office. Then, it was given to the respective zones education offices to facilitate data collection process. Accordingly, all schools were approached via their districts education office. After discussing the main purpose of the research with school principals, study participants were selected. Participation in the study was voluntary and their confidentiality was ensured by omitting personal identifiers. The right of respondents to continue or withdraw from the study at any time was respected. We want to disclose that Gamachu and Ramato (2018) while receiving information for the first objective already published on Journal of Equity in Science and Sustainable Development employed exactly the same procedures.

\section{Results}

The results of study are presented according to its objectives one by one below. For this study purpose, 488 teachers were participated with the response rate of $93.3 \%$. From the total study participants, $70.9 \%$ of them were reported as they were come across national examination cheating during 2014 and 2015 academic year (see figure 1 below).

In harmony with quantitative result, analysis of qualitative data suggested that how examination was given long years ago and how it is given nowadays has great difference. The key informants noted that particularly in remote areas schools the situation go beyond control of invigilator, supervisors and center chef as well. It was found that since the schools have gotten result based aid given by nongovernmental organization, all stakeholders participated on it to make their students pass the exam in huge number if possible $100 \%$. Participants suggested that, as concerned parts do not worry about the ability of the students, they simply need their students to score passing mark. The focus group discussant at Arsi Negele tried to explain the severity of irresponsible act of academic misconduct by Amharic proverb “P片 justifies the means. 


\section{Figure 1: Shows perceived level of cheating encountered during national examination in 2014 and 2015} years March, 2017

In this study the opinion of teachers regarding absence of conducive examination room, presence of social linkage, poor supervision, parental pressure were known to be significantly associated with teachers national examination cheating encountered. On the other hand, insufficient payment, presence of corruption, poor teaching, students give much value for certificate and shortage of qualified teachers were not found to statistically significant relationship with Ethiopian national examination cheating encountered by teaches in the study setting( see table1 below).

Considerable number of key informants assumed that an old hand teaches were fatigued and reluctant while young teachers lack experience and may let the candidates. Additionally, the way teachers were assessing their students in the teachers made assessment was found to be at risk. Most of the key informants reported that there are some irresponsible teachers who give continuous assessment result carelessly. According to these participants this is mainly due to such teachers want to get cheap popularity from students and school principals who is worried to develop students result in irregular way. Participants assumed that some irresponsible school principals take those teachers as role model and recognize their unprofessional practices of adding unnecessary marks and make them to get different opportunity in the schools.

Consequently, well-committed teachers and those who evaluate students carefully were badly treated in many schools by their students and school directors. Because, their efficiency result is directly related to number of students pass examination by their subject matter. If a lot of students fail by his/her subject, that teacher will fail by his/her efficiency result. Therefore, in order not to fail by their efficiency, the teachers were eager to add mark to help students pass examination in huge number.

Apart from the above cases, the finding suggested that there is high tendency of national examination misconduct before it reaches to the hands of the candidates due to lack of care while it was transported from the center to zonal education office, district and different kebeles. This is because; it was not transported with single trip. Interviewees noted that shortage of transportation is due to number of students enrolled to school is increasing at alarming rate by implication demands expansion of schools in every villages. Besides, it was reported that the packet of exam booklet was worn-out and contribute for exam booklet theft. Therefore, this implies that there is high tendency of exam theft while giving back answer sheet to national examination agency.

Many participants including office heads have a view that the main problem encountering is money allocate for perdiem use to pay for different examination bodies. According to these key informants because, the perdiem paid for examinee could not cover cost of transportation, food, bedrooms and other necessary things wanted by them. For this reason, many role model invigilators selected from different district would be reluctant to go to schools for invigilating examination. Since invigilators are not motivated for this purpose, the perfection on examination control would be decreased.

Consequently, senior heads of examination and research at Bale zone education office reported the effort made by his office to make per dime attractive and reduce variation from one center to another through reporting to examination agency. However, his many ups and downs did not fruitful yet. Conversely, this official reported one good commencement done by government last year while grade $12^{\text {th }}$ national examination was given for second time after it is being stolen. That is the agency directly transported chiefs with national examination from center to schools with their own transportation and guards.

Senior teachers who participated in this study assumed that the way students thought at early foundation; grade one to four by one teacher is a prime causes for students misbehavior in upper class. They further explain that because, the teachers teaching in self-content grades teach all subjects whether they have ability or not on these all subjects. However, those teachers who teach in self-content classes have no similar ability on all subjects given in these grades. Since, the teachers do not teach all the subject to achieve the objective intended to be 
measured, students take part on exam theft during national examination.

In harmony with teachers, senior education officer at Bale zone education office goes further as the education policy of self -content given in lower grades has no problem. However, the problem was on how teachers are assigned on self-content class. Teachers were not assigned on self-content grades based on their ability, interest and work experience. They were simply assigned randomly.

According to this official, most of the time innocent and inexperienced teachers were assigned in self-content grades. Especially nowadays, since there is scarcity of teachers on the market, those students who complete grade $10^{\text {th }}$ or $12^{\text {th }}$ are assigned to teach self-content grades without taking any sort of training. This is directly contributing for the decline of education quality. From his view, we can conclude that in system of education, students want to apply the experience they develop in lower grades in high schools and preparatory schools. If students do not develop confidence in lower grades, they will participate on exam theft either in class room test or national examination given in grade ten or twelve.

Table 1: Shows the Association Between Predictors and Teachers National Examination Cheating Encounter March, 2017.

\begin{tabular}{|c|c|c|c|c|c|}
\hline \multirow[t]{2}{*}{ Variables } & \multicolumn{2}{|c|}{$\begin{array}{l}\text { Cheating } \\
\text { encounter }\end{array}$} & \multicolumn{2}{|c|}{ OR $(95 \%$ CI $)$} & \multirow[t]{2}{*}{$\begin{array}{l}\text { P- } \\
\text { value }\end{array}$} \\
\hline & Yes & No & Crude & Adjusted & \\
\hline \multicolumn{6}{|c|}{$\begin{array}{l}\text { lack of conducive examination } \\
\text { room }\end{array}$} \\
\hline Yes & 205 & 58 & $.28(.13, .63)$ & $.119(.039, .37)$ & $.000 * *$ \\
\hline No & 127 & 70 & $.55(.25,1.22)$ & $.267(.087, .817)$ & $.021 * *$ \\
\hline I don’t know & 14 & 14 & 1 & 1 & \\
\hline \multicolumn{6}{|l|}{ Insufficient payment } \\
\hline Yes & 221 & 76 & $1.075(.465,2.48)$ & $1.78(.470,6.764)$ & .396 \\
\hline No & 100 & 58 & $1.812(.767,4.28)$ & $2.632(.675,10.27)$ & .163 \\
\hline I don’t know & 25 & 8 & 1 & 1 & \\
\hline \multicolumn{6}{|l|}{ Presence of social linkage } \\
\hline Yes & 244 & 54 & $.27(.14, .51)$ & $.27(.12, .615)$ & $002 * *$ \\
\hline No & 74 & 65 & $1.07(.56,2.04)$ & $.835(.36,1.95)$ & .677 \\
\hline I don’t know & 28 & 23 & 1 & 1 & \\
\hline \multicolumn{6}{|l|}{ Poor supervision } \\
\hline Yes & 251 & 68 & $.120(.047, .304)$ & $.146(.051, .421)$ & $001 * *$ \\
\hline No & 67 & 58 & $.29(.11, .74)$ & $.293(.099, .86)$ & $.026 * *$ \\
\hline I don’t know & 7 & 16 & 1 & 1 & \\
\hline \multicolumn{6}{|l|}{ Poor teaching } \\
\hline Yes & 141 & 53 & $1.281(.547,3.00)$ & $1.287(.331,5.008)$ & .716 \\
\hline No & 177 & 81 & $1.539(.669,3.54)$ & $1.5(.431,5.9)$ & .483 \\
\hline I don't know & 28 & 8 & 1 & 1 & \\
\hline Students' lack of confidence & 294 & 100 & $1.36(.38,4.92)$ & $1.36(.32,5.80)$ & .68 \\
\hline Yes & 40 & 39 & $3.90(1.02,14.90)$ & $3.14(.68,14.55)$ & .14 \\
\hline No & 12 & 3 & 1 & 1 & \\
\hline \multicolumn{6}{|c|}{ I don’t know } \\
\hline \multicolumn{6}{|c|}{$\begin{array}{l}\text { Students give much value for } \\
\text { certificate }\end{array}$} \\
\hline Yes & 209 & 73 & $.56(.30,1.11)$ & $.563(.211,1.505)$ & .252 \\
\hline No & 109 & 52 & $.79(.40,1.56)$ & $.874(.315,2.424)$ & .795 \\
\hline I don’t know & 28 & 17 & 1 & 1 & \\
\hline \multicolumn{6}{|l|}{ Parental pressure } \\
\hline Yes & 135 & 57 & $1.69(.76,3.73)$ & $3.49(1.16,10.54)$ & $.026 * *$ \\
\hline No & 175 & 76 & $1.74(.80,3.78)$ & $3.06(1.05,8.95)$ & $.041 * *$ \\
\hline I don’t know & 36 & 9 & 1 & 1 & \\
\hline \multicolumn{6}{|l|}{ Shortage of qualified teachers } \\
\hline Yes & 118 & 52 & $1.08(.499,2.344)$ & $.887(.199,3.95)$ & .875 \\
\hline No & 201 & 79 & $.776(.457,2.038)$ & $.687(.156,3.02)$ & .619 \\
\hline I don’t know & 27 & 11 & 1 & 1 & \\
\hline
\end{tabular}

Discussion

In this research, it was found that the overall prevalence of national examination cheating experienced by teachers 
were found to be $70.9 \%$. The study tried to identify teachers' perceived predictors of national examination malpractice. Accordingly, those teachers who respond as lack of conducive examination room predispose for national examination cheating were 8.4 times more likely to encounter examination cheating compared to their counter parts $(\mathbf{A O R}=\mathbf{. 1 1 9 , 9 5 \%} \mathbf{C I}=\mathbf{( . 0 3 9 , . 3 7 )})$. Our result is related to Felix (2015) that poor school environment and infrastructures contribute immensely to poor academic performance and high rate of examination malpractice.

It was identified that presence of social linkage was found to be statistically significant relationship with national examination cheating. The odds of cheating was 3.7 times higher when there was linkage between actors

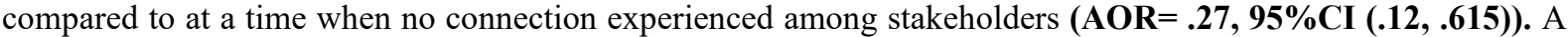
study conducted in Kenyan secondary schools agree with our result that one way through which national examination malpractice happen is by colluding with subject teachers and leakages among others (Nyamoita, \& Otieno, 2016).

In this study, poor examination supervision was identified to be significant predictor of examination cheating encounter. In the presence of poor supervision the odds' of national examination cheating is more than 6.8 times when compared to condition where examination held under strict condition $(\mathrm{AOR}=\mathbf{. 1 4 6 , 9 5 \%}$. $\mathrm{CI}(\mathbf{. 0 5 1}, \mathbf{. 4 2 1}), \mathbf{p}$ Value $\mathbf{= 0 . 0 0 1}$ ). This finding is congruence with Adow et al. (2015) research on the relationship between examination cheating and lack of effective supervision.

At the schools where there were parental pressure to see the results of their students by any means the odds of national examination cheating encounter among teachers were nearly 3.5 times higher than in the schools where there were no parental pressure at all $(\mathrm{AOR}=\mathbf{3 . 4 9}, \mathbf{9 5} \% \mathrm{CI}(\mathbf{. 1 . 1 6}, \mathbf{1 0 . 5 4})$, $\mathbf{p}-\mathrm{Value}=\mathbf{0 . 0 2 6}))$. Akin to our findings, Olatunbosun (2009) came up with the finding that parents and guardians are ready to give encouragement and pay costs because they desperately want their children and wards to acquire certificates.

On the other hand, insufficient payment, presence of corruption, poor teaching, students give much value for certificate and shortage of qualified teachers were not found to be statistically significant relationship with Ethiopian national examination cheating encountered by teaches in the study setting during 2014 and 2015 academic years. But corroboration is confirmed in the data analysis via triangulation therefore, qualitative result suggested that the aforementioned variables are kin to exam misconduct. For example, there was complaining from invigilators about perdim paid for examination bodies while they were invigilating national examination. Similar study in secondary schools of Pakistan by Suleman et al.(2015) have publicized that alongside other factors, economic problem of examination bodies are among many more determinants of examination cheating.

Presence of corruption is also reported by key informants clearly. Other study has also shown unfairness in education convey a wrong message to the younger generation because it teaches them that cheating and bribing is an acceptable way to advance their careers that personal efforts and merit do not count (Hallak \& Poisson, 2007).

Since many students aim was to attend vocational school and learn different skill like driving license, they do not need to learn accordingly and want to score good result. Similarly, other research confirmed that promotion of academic integrity involves students' understanding and concern for core academic values, such as honesty, fairness, responsibility, and respect (Stanculescu, 2013).

\section{Conclusion}

As found in this research, the magnitude of national examination cheating during 2014 and 2015 academic calendar was $70.9 \%$. The determinants of national examination cheating are highly complicated. With regard to determinants national examination cheating absence of conducive examination room, presence of social linkage ,poor supervision, parental pressure were known to be significantly associated with teachers national examination cheating encounter during 2014 and 2015 academic years. Likewise, there is tendency of national examination misconduct before it reaches to the hands of the candidates due to lack of care while it was transported from the center to zonal education office, woredas and different kebels.

The way teachers were assessing their students in their teacher made assessments were found to be at risk which results in dependency among learners. Since per dime paid for examinee could not cover cost of transportation, food, bedrooms and other necessary things wanted by them, examination bodies are not motivated for this purpose, the perfection on examination control would be decreased. It was also found that how students thought at lower grade up grade 4 is contributing for exam cheating in some extent in higher classes. It was also found that the schools were competing each other to pass many students by any means just to get result based aid given by nongovernmental organization depending the number of students who passed examination therefore; it can be a source of cheating since stakeholders are using it in the wrong way.

\section{The way forward}

- The regional educational bureau, zonal and district education educational offices should strengthen their work to make examination rooms more conducive.

- Due attention should be given to how teachers assigned in self -content class in first primary cycle and each schools should needs to have a system which encourage well-committed teachers. 
- $\quad$ There should be strict monitoring and evaluation system with regard to student assessment and the result based aid given by donors should be used before examination in the process of teaching learning so as to improve quality of education which in turn enables schools to have good result from students.

- Provision of optimum finance for examination bodies and availing sufficient logistics like transportation facility is very critical and strong supervision system should be established by zonal and district educational offices.

- Teachers should be governed to the ethical and professional standards of assessment

\section{Conflict of interest}

There is no conflict of interest among researchers and we ensure you that we will be responsible for any conflict of interest that may arise

\section{References}

Adeyemi, O. T. (2010). Examination malpractices among secondary school students in Ondo State, Nigeria: Perceived causes and possible solutions. Journal of Education Administration and Policy Studies Vol. 2(3), pp. 48-55.

Adow, M. I, Alio, A. A., \& Thinguri, R. (2015). An Assessment of the Management of Kese Examination and Its Influence on Irregularities among Students: A Case of Secondary Schools in Mandera County, Kenya. Journal of Education and Practice Vol.6, No.28. ISSN 2222-1735 (Paper)

Alutu, G.N. A. , \& Aluede, O. (2006). Secondary Schools Student's Perception of Examination Malpractices and Examination Ethics. J. Hum. Ecol., 20(4): 295-300.

Bong, M. (2008). Effects of Parent-Child Relationships and Classroom Goal Structures on Motivation, HelpSeeking Avoidance, and Cheating. The Journal of Experimental Education, 76(2), 191-217.

Felix, O. (2015). Causes Of Examination Malpractice In Nigeria Schools. British Journal of Education Vol.3, No.7, pp.34-41.

Gamachu, G. B \& Ramato, A. N. (2018). Perceived Actors of National Examination Cheating: The Case of Bale and West Arsi Zones' Secondary and Preparatory Schools, Oromia Region, Ethiopia. Journal of Equity in Science and Sustainable Development Vol. 2(1):54-61

Hallak, J. , \& poisson, M. (2007). Corrupt schools, Corrupt Universities: What can be done? International institute for educational planning. UNESCO

Khodaie, E. , Moghadamzadeh, A. , \& Salehia, K. (2011). Factors Affecting the Probability of Academic Cheating School Students in Tehran. Procedia - Social and Behavioral Sciences 291587 - 1595

Kyei, A. K. (2014). Inclining Factors Towards Examination Malpractice among students in Takoradi Polytechnic, Ghana. Journal of Education and practice. Vol. 5 (22)

Lee, E. D. (2014). Cheating in the Classroom: Beyond Policing, The Clearing House: A Journal of Educational Strategies, Issues and Ideas. The Clearing House: A Journal of Educational Strategies, Issues and Ideas 82:4, $171-176$

Nyamoita, B. G. , \& Otieno, K. (2016). Effectiveness of Kenya National Examinations Council Measures in Curbing National Examination Malpractices in Public Secondary Schools in Kisii County. International Journal of scientific research and management (IJSRM) Volume 4 Issue 02 3882-3907

Olatunbosun, B. J. (2009). Examination Malpractice In Secondary Schools In Nigeria: What

Onuka, U.O. A. , \& Durowoju, O. E. (2013). Stakeholders' Role in Curbing Examination Malpractice in Nigeria. International Journal of Economy, Management and Social Sciences. 2(6)

Onuka, A.O.U. \& Amusan, M. A. (2008). Causes, effects and probable solutions to examination malpractices: A case study of the West Examinations

Stanculescu, E. (2013). Affective Tendencies in Embarrassing Situations and Academic Cheating Behavior. Procedia - Social and Behavioral Sciences $78723-727$

Suleman, Q. , Gul, R. , Ambrin, S. , \& Kamran, F. (2015). Factors Contributing to Examination Malpractices at Secondary school level in Kohat Division, Pakistan. Journal of Educational Learning.Vol.9 (2) PP.165-182. 